REVIEWS

\title{
Cardiovascular disease risk factors for women. A life course-events perspective
}

\author{
C. J. Hobel ${ }^{1,2}$, Chander P. Arora' ${ }^{1,2}$ \\ ${ }^{1}$ Cedars-Sinai Medical Center, Burns-Allen Research Institute and the Division of Maternal-Fetal Medicine \\ 8635, West Third St., Ste 160W, Los Angeles, CA, USA, 90048 \\ ${ }^{2}$ David Geffen School of Medicine, University of California Los Angeles \\ 10833, Le Conte Avenue, Los Angeles, CA, USA, 90095 \\ calvin.hobel@cshs.org; arora@cshs.org
}

\begin{abstract}
Cardiovascular disease (CVD) in women is the most common cause of death and in 2009 accounted for one third of all deaths. The purpose of this paper is to present what conditions during pregnancy and during the pre-menopause period lead to a greater risk of CVD. The early recognition and the application of interventions may decrease this risk. To emphasize this point we have taken a "Life course-events perspective». Current data suggests that genetic predisposition to disease in conjunction with behavior and environmental factors during fetal life is related to permanent changes in fetalplacental-maternal physiology and function, resulting in fetal programming characterizing the phenotype of the child which may persist into adulthood. Longitudinal studies have identified biological, behavioral and environmental factors related to childhood diseases such as hypertension, insulin resistance and mental health disorders. Gender differences have been identified and animal studies have suggested that estrogens in women are protective and when the risk of CVD in men is considered, the risk in women is delayed by 10 years. Thus, a normal pregnancy may be protective and reduce the risk of CVD in women. However, hypertension developing in women before or during pregnancy is a significant risk factor for women and diabetes further increases this risk of CVD, as does smoking. It is very clear that an «intervention action plan» must be developed. It is the current opinion of the authors that this action plan must be implemented early in life to decrease the risk for the development of CVS in women.
\end{abstract}

Keywords: cardiovascular disease, women, pregnancy.

Introduction. When does the risk for cardiovascular disease (CVD) begin? Why wait for the disease to develop? Is it time to begin interventions early in life if the risk for this disease has been determined? The purpose of this paper is to link two important concepts; first, the «fetal origin of diseases that occur later in life» such as hypertension, diabetes and atherosclerosis, based upon the Barker hypothesis which proposes that these diseases have their origin during fetal life [1]. Second, that «behavioral practices and environmental

(C) Institute of Molecular Biology and Genetics NAS of Ukraine, 2010 exposures associated with inherited and acquired genetic changes increases the risk of disease during fetal life», prior to pregnancy for the woman, during pregnancy for the fetus and mother, infancy and adolescence (Figure, Phase $I$ ) [2, 3].

Background. Matched for age white women are at lower risk of coronary heart disease relative to white men; however, there are recent publications to suggest that certain female children and adolescents are at risk for hypertension and insulin resistance $[4,5]$; some women with a history of prior pregnancies are at increased risk during the interval between pregnancies 
Phase I
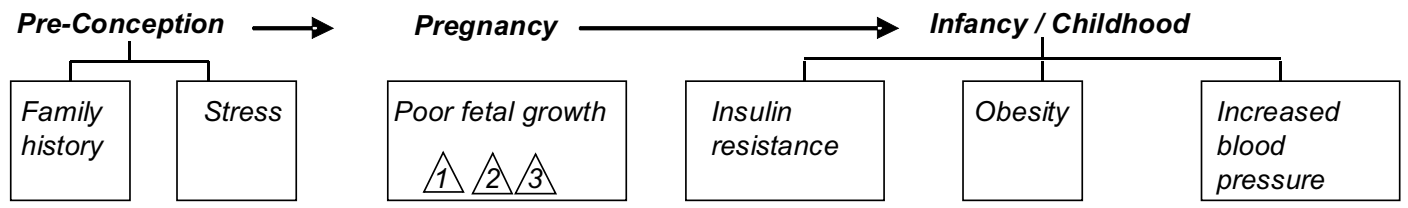

Genetics

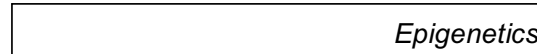

Phase II Reproductive years (Pregnancy effect)
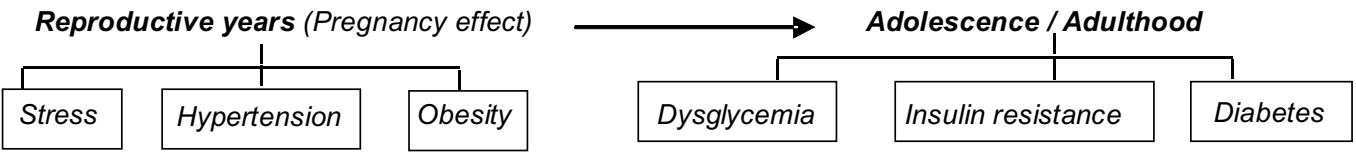

\section{Premenopause}

Phase III
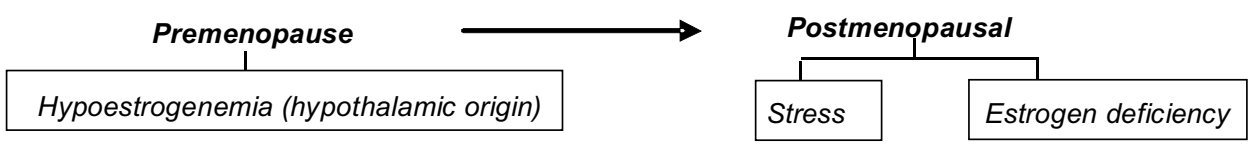

Risk factors

$\bigwedge$ First trimester

2 Second trimester

3. Third trimester

This figure divides the Life Events-Course into three phases. Phase I is the period beginning before pregnancy and extended through out the gestational period into infancy and childhood. Phase II begins during the reproductive years and extends to the peri-menopausal period where reproductive performance is near zero. Phase III begins during the pre-menopausal period and the end is a terminal event

and within the next 15 years suggesting that certain conditions during pregnancy increases their risk of hypertension, diabetes and atherosclerosis, and finally women during the premenopausal period with hypoestrogenemia of hypothalamic origin have a greater risk of coronary artery disease than those with normal menstrual cycles $[6,7]$, thus identifying a group of women at an earlier age that are at risk (Figure, Phase II).

It is well know as women enter the post menopause period the incidence of coronary heart disease almost equals that in men [8]. This subject is important for three reasons. First, CVD is the leading cause of death for both men and women and the second reason is that the proportion of life lost is higher (18\%) in developed countries and approximately $10 \%$ in developing countries and in the later the rates are increasing. These data suggest that there is something unique in developed countries that place women at risk which could have a behavioral, nutritional, environmental or epigenetic basis. Third, CVD in women is the most common cause of death and accounts for one third of all deaths [9]. More women than men have died from CVD causes on a yearly basis since the mid 1980's. One reason for this disparity was the failure to include women in clinical trials which appeared to be primarily designed for men, which lead the National Institutes of Health to implement a policy in 1986 to include more women in clinical trials (Figure, Phase III). Thus, the purpose of this paper is to take a «life course-events perspective» and review the literature to identify what conditions prior to pregnancy, during pregnancy and prior to menopause lead to a greater risk of CVD whereby the early recognition of risk and the application of interventions could decrease the risk of coronary artery disease [10-13].

The life course-events perspective and the origin of adult diseases. Fetal programming. Today it is well recognized that changes in the environment during the period of fetal development, is associated with permanent changes in physiology and function [2]. Some of the changes are the result of gene alterations by epigenetic factors such as DNA methylation and histone changes [3]. Several studies by the epidemiologist, David Barker in the United Kingdom documented the influences of prenatal factors on the risk of developing hypertension, diabetes mellitus and atherosclerosis $[14,15]$. The factors associated with this risk of disease was determined to be related to those conditions related 
to poor fetal nutrition and reduced size at birth [16]. The timing of these associated events has been determined to be important. Early first trimester under nutrition was primarily related to the development of hypertension later in adulthood, while poor fetal nutrition during the second trimester was associated with a greater risk of developing diabetes, while poor nutrition during the third trimester was associated with hypertension and stroke [1] (Figure, Phase I).

Thus, small size at birth secondary to poor nutrition and decreased nutrient supply to the fetus increases the risk for the development of CVD; however, poor fetal growth also plays an important role in making an individual permanently «thrifty» (thrifty phenotype) by being small and insulin resistant and prepared at birth to live under adverse condition which has been referred by James Jones as «The Best of a Bad Start» [17] (Figure, Phase $I$ ). Unfortunately all too often the child is born into an environment of plenty (adequate or excessive food supply) and its phenotype is altered. This process is referred to as the «Thrifty genotype» a hypothesis suggested by Neel who proposed that the thrifty aspects of the contemporary individual who arose from genes selected over a long period of time to survive in an environment in which nutrient supplies were limited but found itself in an environment of plenty and developed obesity and a greater risk of disease [18]. A third example is the «natural short term experiment» such as the Dutch Famine during the Second World War when the Germans formed a blockade of Holland argues against a purely genetic basis. Only hunger during the last part of pregnancy for Dutch women did the hunger effect fetal growth and the risk of disease in later life [19]. The effect of short term nutrition deprivation (adverse event) could occur because of epigenetic changes that occur within the fetus resulting in genetic changes which increase the risk of a subsequent disease.

Cumulative pathway during infancy, childhood and adolescence. Several longitudinal studies have been carried out which have identified biological, behavioral and environmental factors related to childhood diseases such as hypertension, insulin resistance and mental health disorders which could contribute to the development of adult diseases [20]. The classic study by Rutter et al. on the long term effects of severe de- privation of Romanian orphans after adoption [21]. Two theories were considered. First, one was based on the idea of physiological plasticity due to biological programming similar to that which occurs in intra uterine programming. Second, was based upon environmental exposures that disrupted normal development such as maternal smoking, alcohol consumption and toxins, all or which can cause minimal brain pathology and/or adverse behavioral consequences. At this point it is sometimes difficult to sort out what are changes in plasticity (adaptive changes) and what is the result of pathological changes leading to minimal brain dysfunction.

\section{Gender differences in the risk of cardiovascular} disease. Developing within the past 10 years there has been evidence that arterial disease in both sexes' begins early in life (Barker Hypothesis); however, overtime the progression of CVD in women compared with men is delayed and/or increased by approximately 10 years. What is the primary protective mechanism?

Important animal primate studies. The research carried out by Thomas Clarkson in the nonhuman primate model (Cynomolgus macaque) has been helpful to understand the influence of estrogens on the development of atherosclerosis. This research group has shown that the macaque monkey like premenopausal white women are protected against coronary artery atherosclerosis [22-24]. In these studies these investigators showed that ovariectomy and the relative estrogen deficiency that accompanies low social status in female monkeys are both associated with a loss of «female protection» against coronary artery disease. In 1987 these investigators showed that repeated pregnancy (increased window of estrogen exposure) is also associated with a marked reduction in the extent of diet-induced coronary artery atherosclerosis and provided evidence that endogenous estrogen has an inhibitory effect on the atherosclerotic process [25]. These studies formed the basis for studies in the human.

Important human studies. Stimulated by the higher gender specific coronary mortality observed in women, Bairey Merz et al. tested the hypothesis that hypoestrogenemia of hypothalamic origin is associated with coronary artery disease in young women who were studied in the Women's Ischemia Syndrome Evaluation (WISE) [26-28]. Bairey Merz showed that 
premenopausal women with angiographic coronary artery disease had significantly lower estradiol and follicle-stimulating hormone levels than women without angiographic findings, even after controlling for age [7]. This study was the first time that hypoestrogenemia of hypothalamic origin was found to be associated with coronary artery disease in premenopausal women. Her findings supported the concept that female protection is lost when ovarian function is disrupted and that this finding is consistent with previous primate work noted above initiated by Clarkson et al.

Is hormone replacement therapy effective? Exogenous hormone therapy (HT) may have antiatherosclerotic effects [29, 30]. However, recent clinical trials have failed to show protective cardiovascular effects in postmenopausal women [31-33]. Recently Bairey Merz et al. assessed the relationships between detailed measurements of endogenous and exogenous estrogen exposure time with angiographic coronary artery disease and major adverse cardiovascular events [34]. These investigators found no independent relation of estrogen exposure time to angiographic coronary artery disease or major adverse cardiovascular events in women being evaluated for suspected ischemia. These results suggest that the concept of estrogen protection for this disease in women is more complex than estrogen exposure duration alone.

Does pregnancy have an effect on the subsequent development of cardiovascuar disease? Beginning in the early 60's and 70's investigators began to address the relationship between the number of pregnancies and atherosclerosis and the results were controversial; however, recently it has been brought to our attention that pregnancy can be a prodrome to vascular dysfunction and cardiovascular risk in some women [6, 35]. In 1964 a paper published by Win kelstein and Rakate showed that there were an excess of pregnancies in women dying of coronary heart disease and then a paper published in 1974 by Berngtsson, Rybo and Westerberg showed similar findings $[36,37]$. Three other studies provided no evidence for an association between coronary heart disease risk and the number of pregnancies [38-40]. Then years later in 1984 Beard, Fuster and Annegers, found that women whose first pregnancy was before the age of
25 were found to be at greater risk of coronary heart disease [41]. The importance of this paper was the focus toward confounding variables such as lower socioeconomic status, lower educational levels and psychosocial variables in younger women that could contribute to the risk of coronary heart disease. The role of psycho- social factors will be discussed below in the section titled stress and the risk of CVD.

Hypertension and the risk of cardiovascular disease. Beginning in 2001 several large population studies began to show that hypertensive disorders in pregnancy (preeclampsia and gestational hypertension) were makers of future risk of CVD [42-44]. In 2007 a meta analysis by Bellamy et al. showed an interrelationship between risk factors and that hypertensive disorders were clearly related to a great risk of CVD in later years [45]. Most studies have shown that there are other common risk factors associated with hypertensive disorders in pregnancy, such as higher blood pressure prior to clinical disease, obesity, elevated lipids and gestational diabetes.

It is important to discuss the most recent paper published by Magnussen et al. in Norway on the association between hypertension in pregnancy and the risk of CVD. These investigators linked data from the Medical Birth Registry to a large population based health survey (HUNT study) to assess the association of hypertensive disorders in pregnancy with cardiovascular risk factors assessed approximately 28 years later (mean duration of subject participation in this study was 23 years) [46]. These investigators identified 13,623 subjects with no hypertensive disorders and 1,433 with hypertensive disorders. Women who developed preeclampsia or gestational hypertension had significantly higher body mass indices (BMI's) and abnormal lipid profiles. In addition the analysis showed that associated risk factors became stronger with increasing maternal age and parity. Finally these investigators showed that women with hypertensive disorder in pregnancy were also significantly more likely to develop diabetes at follow up suggesting that they may have had some degree of insulin resistance during pregnancy.

This study also clearly show that both preeclampsia and gestational hypertension most likely share a similar pathological mechanism leading to a greater risk of CVD, but that the «condition of pregnancy» (normal group followed) is not related to the risk of CVD. 
Thus, it appears that there is some form of endothelial dysfunction that occurs in subjects who develop hypertensive disorders of pregnancy. In addition there appears to be three additional risk factors that may contribute to this risk. First, is that recurrent pregnancy (increased parity) could be a prodrome or dose effect to increase the risk. Second, is that the increase incidence of obesity could play a role in the development of insulin resistance and diabetes later (at follow up) which brings up the issue as to whether or not women at risk for hypertension may also have a co-morbid risk for developing insulin resistance during the pregnancy without having made the diagnosis of pre-diabetes or gestational diabetes. This will be discussed below. Third, psychological factors are also thought to play an important role in the development of hypertension and it may also be an important factor in the development of the risk of CVD [47]. This will also be discussed below. Finally, maternal age associated with increasing parity could itself increase the risk of atherosclerosis. Maternal age has been shown to be an independent risk factor for CVD disease and the history of prior hypertension and the recurrent cardiovascular stress associated with pregnancy and or adverse life style may play an important role over time [48, 49].

What is the association between dysglycemia and diabetes and the risk of cardiovascular disease? The Framingham Study initiated between 1948 and 1952 in the United States studied 5070 men and women who were originally free of CVD when first examined and who later developed various manifestations of CVD between the ages of 35 and 64 . In 1987 a report on the Framingham Study by Stokes et al. on the relative importance of selected risk factors 30 years later on the risk of various manifestations of CVD (stroke, congestive hear failure, coronary heart disease and intermitted at claudication) found that hypertension contributed most consistently to short term risk of all manifestations of CVD [8]. An important part of this early report was the observation that there were significant differences between the sexes and age groups. One important finding was that diabetes was reported to be a significant risk factor for total CVD risk for both men and women.

At about this same time in 1987 investigators began to focus on the importance of family history as an inde- pendent risk factor for incident coronary artery disease. A report by Hopkins et al. showed that after controlling for age, sex, total cholesterol, higher density lipoprotein cholesterol, hypertension, diabetes, cigarette smoking and body mass index, family history remained a highly significant predictor for the development of coronary artery disease [50]. In reference to diabetes this study showed that the incidence of diabetes in the patients who had incident coronary artery disease (CAD) was 18.8 percent compared to 3.4 percent in those without CAD.

Dysglycemia and the risk of cardiovascular disease. Dysglycemia was listed above in the section on the risk of CVD. For the purpose of this discussion the definition of this term is «an elevation of glucose values that do not meet the criteria used for the diagnosis of diabetes». The reason for using this term is that it suggests that elevated glucose levels are a continuous variable and that at some point in ones life course-events the values will become abnormal and the subject can be defined as diabetic. One of the most interesting papers published this year was a paper by Retnakaran and Shah who assessed glucose intolerance in pregnancy and the risk of CVD in a population-based cohort study in Ontario Canada [51]. In North America pregnant women commonly receive screening for gestational diabetes mellitus using a 50 gram glucose screening test (GST) and if positive is followed by a glucose tolerance test (GTT) where two abnormal values are required for the diagnosis of gestational diabetes. Thus, women with a positive screen but a negative GTT (which may include one abnormal value) are considered dysglycemic (potentially at risk for diabetes). This study by Retnakaran and Shah stratified their population into 3 cohorts of women: 1) Those with gestational diabetes $(13,888) ; 2)$ women who received a antepartum oral glucose tolerance test because they had a positive screening test $(71,831)$ and 3$)$ those who did not have a GTT presumably because their screen was negative $(349,977)$. During the intervening 12.3 years the women who had gestational diabetes had the highest risk for CVD with an adjusted hazard ratio of 1.66 (1.30-2.13) and next were those with a positive screen but negative GTT with an adjusted hazard ratio of 1.19 (1.02-1.39), when compared to the group with a negative screen. This study was the first to identify a group 
of women most often considered normal (positive screen and negative GTT) yet considered dysglycemic and to be at risk for cardiovascular disease within $12+$ years after the assessment during pregnancy. What is important is that this study suggests that in addition to women with gestational diabetes a subset of women with a lesser degree of antepartum dysglycemia may also benefit from closer cardiovascular surveillance.

Obesity and the risk of cardiovascular disease. Overweight and obesity are associated with the development of hyperlipidemia, hypertension, CVD, insulin resistance, type 2 diabetes and a shorter lifespan [52, 53]. Gunderson et al. assessed the risk for the development of becoming overweight with childbearing by utilizing the CARDIA study data base [54]. The CARDIA study began in 1986 and continued up to 1996 and examined the participants at baseline and again at 2, 5, 7, and 10 years and included black and white nulliparous women who were not overweight at baseline. These investigators found an interesting interaction between the risk factors smoking and parity. Women with 1 and $2+$ births had a significantly increased risk for the development of being overweight if they never smoked compared to a decreased risk for those who were smokers. Thus, smoking decreased the risk of becoming overweight; however, it is well known that smoking is a significant risk factor for CVD. This study also determined that race, frequent weight cycling, less education and less physical activity was also significant risk factors.

Stress and the risk of cardiovascular disease. Our research group has focused considerable time and effort to understand the role of stress and pregnancy outcome $[55,56]$. Hypertension has long been shown to be a strong, independent, and etiologically significant risk factor for developing CVD [47]. Yan L. L. et al. (2003) used the CARDIA study to examine the role of psychosocial factors such as time urgency/impatience (TUI), achievement striving/competitiveness (ASC), hostility, depression, and anxiety on the long-term risk of hypertension [57]. As noted above the CARDIA study was a multi-center, longitudinal study of the development of coronary artery disease risk factors in young adults. This study showed a dose-response increase in the risk of developing hypertension for those who had a higher tendency of urgency/impatience and hostility but not
ASC, depression or anxiety in this young adult cohort. These investigators also recognized that the risk of hypertension appears to differ across different age, race and sex groups which require continued research. The biologically and plausible mechanism of how psychosocial factors increase the risk of hypertension is via the sympathetic nervous system stimulation from acute stress, leading to increased cardiac output, vasoconstriction, arterial pressure elevation and impaired endothelial dysregulation [58]. Recently, Denollet J. et al. assessed the role of anxiety in a 10 year follow-up of middle-aged women who participated in the «Eindhoven Perimenopausal Osteoporosis Study in the Netherlands» [10]. These investigators used a threeitem anxiety scale to assess primary outcomes of an allcause mortality at 10-year follow-up and secondary outcomes related to cardiovascular and lung/breast cancer death [59]. Smoking, living alone and lower education were related to mortality, but depression was not. Adjusting for these variables, anxiety was associated with a $77 \%$ increase in mortality risk and it was related to cardiovascular death. The authors summarized their findings by stating that anxiety appears to be related to unhealthy lifestyles such as smoking, obesity, inactivity, hypertension and diabetes and that these factors may mediate the anxiety-mortality relationship.

Smoking and the risk of cardiovascular disease. All of the studies that we reviewed for the assessment of risk factors and CVD identified smoking as a significant risk factor. Campbell et al. recently reviewed the metabolic effects of cigarette smoking and individuals who smoke experience a wide range of physiologic side effects that increase the risk of CVD, including insulin resistance, elevated catecholamine levels which contribute to an elevated heart rate and blood pressure, and hypercholesterolemia [60]. However, as noted above the study by Gunderson showed that smoking during pregnancy was protective and prevented women from gaining excessive weight during pregnancy and it is also well known that women who smoke during pregnancy are less likely to develop preeclampsia which like obesity increases the risk of developing CVD. The interesting paper by Ness et al. assessed the interaction between weight gain during pregnancy and its association with the protective effect of smoking on the development of preeclampsia [61]. 
Among underweight and normal weight women, smoking decreased the risk of preeclampsia after adjustment for maternal age, race and socioeconomic status. However, among overweight/obese women this trend was not apparent and among both underweight and overweight women, smoking significantly increases the risk of delivering a small for gestational aged fetus (SGA). Obesity eliminated the inverse association between smoking and preeclampsia.

Action for the prevention of cardiovascular diseases in women. Both American Heart Association and the World Health Organization have developed specific recommendations. Because CVD is the single leading cause of death and a significant cause of morbidity in the United States and Globally and an «Action Plan» must be implemented early in the life eventcourse of women because the risk factors for CVD are and finally the treatment. The ultimate and primary well documented and there is compelling data from epidemiological studies and randomized clinical trials to show that this disease is largely preventable. A «Guide to Preventive Cardiology for Women» was approved by the American College of Cardiology in 1999 and by the American heart Association in 1998 and published in 1999 [13]. This guide to risk reduction for women addresses the goals, screening methods and recommendations for smoking cessation, physical activity, nutrition, weight management, psychosocial factors, blood pressure, lipids and lipoproteins, diabetes, hormone replacement therapy, oral contraceptive, and cardiovascular drugs.

The World Health Organization provides a structured life course-events perspective [12]. First, WHO begins by focusing on the risk factors that begin in childhood and youth and then focus on the role of hypertension, lipids, tobacco, physical activity, obesity, diabetes and socioeconomic status as they consider women to be a «special case» when considering risk assessment. The «Action plan» proposed by WHO includes the importance of research, the role of regional organizations and prevention as guided by personal choices, population and system approaches, health education, policies and legislation goal is to prevent death and suffering, but there are also economic implications.
К. Дж. Хобель, Ч. П. Арора

Фактори ризику розвитку серцево-судинних

захворювань у жінок

Резюме

Сериево-судинні захворювання (СС3) у жінок є найпоширенішою причиною смертності, які у 2009 році становили третину всіх випадків смерті. Мета роботи полягає у визначенні причин, які призводять до підвищеного ризику появи ССЗ під час вагітності та у період менопаузи. Рання діагностика і профілактика можуть знизити ризик виникнення ССЗ. Щоб підкреслити важливість извого моменту, ми наводимо рекомендований «Спосіб життя». Ці дані демонструють, щзо генетична схильність до хвороб разом з поведінкою і дією чинників довкілля негативно впливають на плід, фізіологію плаценти іматеринську функиію. Це може призвести до зміни фенотипу у дитини, який зберігається у дорослому віці. Дослідження виявили зв 'язок біологічних, поведінкових та екологічних факторів з дитячими захворюваннями, такими як гіпертонія, інсулінорезистентність і психічні розлади. Встановлено також статеві відмінності, дослідами на тваринах показано, що естрогени захищають жінок від ССЗ і ризик появи останніх відтерміновуються на 10 років. Таким чином, нормальна вагітність здатна захистити та знизити ризик виникнення ССЗ у жінок. Однак гіпертонія, яка розвивається до або під час вагітності, $\epsilon$ значним негативним чинником, щзо поглиблюється діабетом $i$ палінням. Цілком очевидно, щзо потрібно розробити «стратегічний план дій». На думку авторів, такий план дій необхідно реалізувати на початку життя, щоб знизити ризик розвитку ССЗ у жінок.

Ключові слова: сериево-судинні захворювання, жінки, вагітність.

\section{К. Дж. Хобель, Ч. П. Арора}

Факторы риска развития сердечно-сосудистых заболеваний у женщин

Резюме

Сердечно-сосудистые заболевания (ССЗ) у женщин являются наиболее распространенной причиной смерти, в 2009 году они составили треть всех случаев смерти. Цель работы охарактеризовать причины, приводяшие к повышенному риску возникновения ССЗ во время беременности и и в период менопаузы. Ранняя диагностика и профилактика могут снизить риск появ- ления ССЗ. Чтобы подчеркнуть важность этого момента, мы приводим рекомендуемый «Способ жизни». Эти данные показывают, что генетическая предрасположенность $к$ болезням совместно с поведением и действием факторов окружающей среды негативно влияют на плод, физиологию плаценmbl и материнскую функцию. Что может приводить к изменениям фенотипа у ребенка, которые сохраняются во взрослом возрасте. Исследования выявили связь биологических, поведенческих и экологических факторов с такими заболеваниями у детей, как гипертония, инсулинорезистентность и психические расстройства. Установлены также половые различия, анализ исследований на животных позволил предположить, что эстрогены защищзают женщин от ССЗ и риск появления последних у женщин откладывается на 10 лет. Таким образом, нормальная беременность может защитить и снизить риск возникновения ССЗ у женщин. Однако гиперто- 
ния, развивающаяся до или во время беременности, является существенным негативным фактором,который усугубляется диабетом и курением. Совериенно очевидно, что должен быть разработан «стратегический план действий». По мнению авторов, такой план действий должен быть реализован в начале жизни, чтобы снизить риск развития ССЗ у женщин.

Ключевые слова: сердечно-сосудистые заболевания, женщины, беременность.

\section{REFERENCES}

1. Barker D. J. The fetal and infant origins of adult disease // Brit. Med. J.-1990.-301, N 6761.-P. 1111.

2. Gluckman P. D., Hanson M. A., Beedle A. S. Early life events and their consequences for later disease: A life history and evolutionary perspective // Am. J. Hum. Biol.- 2007.-19, N 1.-P. 1-19.

3. Gluckman P. D., Hanson M. A., Cooper C., Thornburg K. L. Effect of in utero and early-life conditions on adult health and disease // N. Engl. J. Med.-2008.-359, N 1.-P. 61-73.

4. Blake K. V., Gurrin L. C., Evans S. F., Beilin L. J., Landau L. I., Stanley F. J., Newnham J. P. Maternal cigarette smoking during pregnancy, low birth weight and subsequent blood pressure in early childhood // Early Hum. Develop.-2000.57, N 2.-P. 137-147.

5. Hofman P. L., Regan F., Jackson W. E., Jefferies C., Knight D. B., Robinson E. M., Cutfield W. S. Premature birth and later insulin resistance // N. Engl. J. Med.-2004.-351, N 21.P. 2179-2186.

6. Banerjee M., CruickshankJ. K. Pregnancy as the prodrome to vascular dysfunction and cardiovascular risk // Nat. Clin. Pract. Cardiovasc. Med.-2006.-3, N 11.-P. 596-603.

7. Merz C. N., Johnson B. D., Sharaf B. L., Bittner V., Berga S. L., Braunstein G. D., Hodgson T. K., Matthews K. A., Pepine C. J., Reis S. E., Reichek N., Rogers W. J., Pohost G. M., Kelsey S. F., Sopko G., and WISE Study Group. Hypoestrogenemia of hypothalamic origin and coronary artery disease in premenopausal women: a report from the NHLBI-sponsored WISE study // J. Am. Coll. Cardiol.-2003.-41, N 3.P. 413-419.

8. Stokes J. $3^{\text {rd }}$, Kannel W. B., Wolf P. A., Cupples L. A., D'Agostino $R$. B. The relative importance of selected risk factors for various manifestations of cardiovascular disease among men and women from 35 to 64 years old: 30 years of follow-up in the Framingham Study // Circulation.-1987.-75, N 6, pt 2.P. V65-73.

9. Kim E. S., Menon V. Status of women in cardiovascular clinical trials // Arterioscl. Thrombos. Vasc. Biol.-2009.-29, N 3.-P. 279-283.

10. Denollet J., Maas K., Knottnerus A., Keyzer J. J., Pop V. J. Anxiety predicted premature all-cause and cardiovascular death in a 10-year follow-up of middle-aged women // J. Clin. Epidemiol.-2009,-62, N 4.-P. 452-456.

11. Mc Gill H. C. Jr., Stern M. P. Sex and atherosclerosis // Atheroscl. Rev.-1979.-4.-P. 157-242.

12. Mackay J., Mensah G. The atlas of heart disease and stroke.Geneva: WHO press, 2004.-112 p.

13. Mosca L., Grundy S. M., Judelson D., King K., Limacher M., Oparil S., Pasternak R., Pearson T. A., Redberg R. F., Smith S. C. Jr., Winston M., Zinberg S. AHA/ACC scientific statement: consensus panel statement. Guide to preventive cardiology for women. American Heart Association/American Col- lege of Cardiology // J. Am. Coll. Cardiol.-1999.-33, N 6.P. 1751-1755.

14. Barker D. J., Hales C. N., Fall C. H., Osmond C., Phipps K., Clark P. M. Type 2 (non-insulin-dependent) diabetes mellitus, hypertension and hyperlipidaemia (syndrome $\mathrm{X}$ ): relation to reduced fetal growth // Diabetologia.-1993.-36, N 1.P. 62-67.

15. Law C. M., Barker D. J., Richardson W. W., Shiell A. W., Grime L. P., Armand-Smith N. G., Cruddas A. M. Thinness at birth in a northern industrial town // J. Epidemiol. Commun. Health.-1993.-47, N 4.-P. 255-259.

16. Godfrey $K$. The developmental origins hypothesis: Epidemiology // Developmental origins of health and disease / Eds P. Gluckman, M. Hanson.-Cambridge: Univ. press, 2006.P. 1-32.

17. Jones $J$. H. Fetal programming: adaptive life-history tactics or making the best of a bad start? // Am. J. Hum. Biol.-2005.17, N 1.-P. 22-33.

18. Neel J. V. Diabetes mellitus: a «thrifty» genotype rendered detrimental by «progress»? // Am. J. Hum. Genet.-1962.-14, N 4.-P. 353-362.

19. Painter R. C., Roseboom T. J., Bleker O. P. Prenatal exposure to the Dutch famine and disease in later life: an overview // Reprod. Toxicol.-2005.-20, N3.-P. 345-352.

20. Swanson J. D., Wadhwa P. M. Developmental origins of child mental health disorders // J. Child Psychol. Psychiat.-2008.49, N 10.-P. 1009-1019.

21. Rutter M., O'Connor T. G., English and Romanian Adoptees (ERA) Study Team. Are there biological programming effects for psychological development? Findings from a study of Romanian adoptees // Develop. Psychol.-2004.-40, N 1.-P. 8194.

22. Hamm T. E. Jr., Kaplan J. R., Clarkson T. B., Bullock B. C. Effects of gender and social behavior on the development of coronary artery atherosclerosis in Cynomolgus macaques // Atherosclerosis.-1983.-48, N 3.-P. 221-233.

23. Kaplan J. R., Adams M. R., Clarkson T. B., Koritnik D. R. Psychosocial influences on female «protection» among $C y$ nomolgus macaques // Atherosclerosis.-1984.-53, N 3.P. 283-295.

24. Adams M. R., Kaplan J. R., Clarkson T. B., Koritnik D. R. Ovariectomy, social status, and atherosclerosis in Cynomolgus monkeys // Arteriosclerosis.-1985.-5, N 2.P. 192-200.

25. Adams M. R., Kaplan J. R., Koritnik D. R., Clarkson T. B. Pregnancy-associated inhibition of coronary artery atherosclerosis in monkeys. Evidence of a relationship with endogenous estrogen // Arteriosclerosis.-1987.-7, N 4.P. 378-384.

26. Tofler G. H., Stone P. H., Muller J. E., Willich S. N., Davis V. G., Poole W. K., Strauss H. W., Willerson J. T., Jaffe A. S., Robertson $T$. Effects of gender and race on prognosis after myocardial infarction: adverse prognosis for women, particularly black women // J. Am. Coll. Cardiol.-1987.-9, N 3.P. 473-482.

27. Greenland P., Reicher-Reiss H., Goldbourt U., Behar S. Inhospital and 1-year mortality in 1,524 women after myocardial infarction. Comparison with 4,315 men // Circulation.1991.-83, N 2.-P. 484-491.

28. Merz C. N., Kelsey S. F., Pepine C. J., Reichek N., Reis S. E., Rogers W. J., Sharaf B. L., Sopko G. The Women's Ischemia Syndrome Evaluation (WISE) study: protocol design, methodology and feasibility report // J. Am. Coll. Cardiol.-1999.33, N 6.-P. 1453-1461. 
29. Grodstein F., Manson J. E., Colditz G. A., Willett W. C., Speizer F. E., Stampfer M. J. A prospective, observational study of postmenopausal hormone therapy and primary prevention of cardiovascular disease // Ann. Intern. Med.-2000.-133, N 12.-P. 933-941.

30. Grodstein F., Stampfer M. The epidemiology of coronary heart disease and estrogen replacement in postmenopausal women // Progr. Cardiovasc. Dis.-1995.-38, N 3.-P. 199-210.

31. Herrington D. M., Reboussin D. M., Brosnihan K. B., Sharp P. C., Shumaker S. A., Snyder T. E., Furberg C. D., Kowalchuk G. J., Stuckey T. D., Rogers W. J., Givens D. H., Waters $D$. Effects of estrogen replacement on the progression of coronary-artery atherosclerosis // N. Engl. J. Med.-2000.343, N8.-P. 522-529.

32. Hulley S., Grady D., Bush T., Furberg C., Herrington D., Riggs B., Vittinghoff E. Randomized trial of estrogen plus progestin for secondary prevention of coronary heart disease in postmenopausal women. Heart and Estrogen/progestin Replacement Study (HERS) Research Group // JAMA.-1998.280, N 7.-P. 605-613.

33. Rossouw J. E., Anderson G. L., Prentice R. L., LaCroix A. Z., Kooperberg C., Stefanick M. L., Jackson R. D., Beresford S. A., Howard B. V., Johnson K. C., Kotchen J. M., Ockene J., Writing Group for the Women's Health Initiative Investigators. Risks and benefits of estrogen plus progestin in healthy postmenopausal women: principal results From the Women's Health Initiative randomized controlled trial // JAMA.-2002.-288, N 3.-P. 321-333.

34. Merz C. N., Johnson B. D., Berga S. L., Braunstein G. D., Azziz R., Yang Y., Reis S. E., Bittner V., Hodgson T. K., Pepine C. J., Sharaf B. L., Sopko G., Kelsey S. F., Women's Ischemia Syndrome Evaluation Study Group. Total estrogen time and obstructive coronary disease in women: insights from the NHLBI-sponsored Women's Ischemia Syndrome Evaluation (WISE) // J. Women's Health.-2009.-18, N 9.- P. 13151322.

35. Lesauskaite V., Tanganelli P., Bianciardi G., Simoes C., Toti $P$., Weber $G$. World Health Organization (WHO) and the World Heart Federation (WHF) Pathobiological Determinants of Atherosclerosis in Youth (PBDAY) Study. Histomorphometric investigation of the aorta and coronary arteries in young people from different geographical locations // Nutr. Metabol. Cardiovasc. Dis.-1999.-9, N 6.-P. 266-276.

36. Winkelstein W. Jr., Rekate, A. C. Age trend of mortality from coronary artery disease in women and observations on the reproductive patterns of those affected // Am. Heart J.-1964.67, N 4.-P. 481-488.

37. Bengtsson C., Rybo G., Westerberg H. Number of pregnancies, use of oral contraceptives and menopausal age in women with ischemic heart disease, compared to a population sample of women // Acta Med. Scand.-1973.-549, suppl.-P. 75-81.

38. Kannel W. B., Hjortland M. C., McNamara P. M., Gordon T. Menopause and risk of cardiovascular disease: the Framingham study // Ann. Intern. Med.-1976.-85, N 4.-P. 447-452.

39. Mann J. I., Vessey M. P., Thorogood M., Doll S. R. Myocardial infarction in young women with special reference to oral contraceptive practice // Brit. Med. J.-1975.-2, N 5965.P. 241-245.

40. Restrepo C., Guzman M. A., Eggen D. A., Strong J. P. Pregnancy and atherosclerosis // Atherosclerosis.-1972.-15, N 3.-P. 371-382.

41. Beard C. M., Fuster V., Annegers J. F. Reproductive history in women with coronary heart disease. A case-control study // Am. J. Epidemiol.-1984.-120, N 1.-P. 108-114.
42. Smith G. C., Pell J. P., Walsh D. Pregnancy complications and maternal risk of ischaemic heart disease: a retrospective cohort study of 129,290 births // Lancet.-2001.-357, N 9273.-P. 2002-2006.

43. Wilson B. J., Watson M. S., Prescott G. J., Sunderland S., Campbell D. M., Hannaford P., Smith W. C. Hypertensive diseases of pregnancy and risk of hypertension and stroke in later life: results from cohort study // Brit. Med. J.-2003.326, N 7394.-P. 845.

44. Ray J. G., Vermeulen M. J., Schull M. J., Redelmeier D. A. Cardiovascular health after maternal placental syndromes (CHAMPS): population-based retrospective cohort study // Lancet.-2005.-366, N 9499.-P. 1797-1803.

45. Bellamy L., Casas J. P., Hingorani A. D., Williams D. J. Preeclampsia and risk of cardiovascular disease and cancer in later life: systematic review and meta-analysis // Brit. Med. J.- 2007.-335, N 7627.-P. 974.

46. Magnussen E. B., Vatten L. J., Smith G. D., Romundstad P. R. Hypertensive disorders in pregnancy and subsequently measured cardiovascular risk factors // Obstet. Gynecol.-2009.114, N 5.-P. 961-970.

47. Kannel $W$. B. Blood pressure as a cardiovascular risk factor: prevention and treatment // JAMA.-1996.-275, N 20.P. 1571-1576.

48. Ness R. B., Harris T., Cobb J., Flegal K. M., Kelsey J. L., Balanger A., Stunkard A. J., D'Agostino R. B. Number of pregnancies and the subsequent risk of cardiovascular disease // N. Engl. J. Med.-1993.-328, N 21.-P. 1528-1533.

49. Lawlor D. A., Emberson J. R., Ebrahim S., Whincup P. H., Wannamethee S. G., Walker M., Smith G. D., British Women's Heart and Health Study, British Regional, Heart Study. Is the association between parity and coronary heart disease due to biological effects of pregnancy or adverse lifestyle risk factors associated with child-rearing? Findings from the British Women's Heart and Health Study and the British Regional Heart Study // Circulation.-2003.-107, N 9.P. 1260-1264.

50. Hopkins P. N., Williams R. R., Kuida H., Stults B. M., Hunt S. C., Barlow G. K., Ash K. O. Family history as an independent risk factor for incident coronary artery disease in a high-risk cohort in Utah // Am. J. Cardiol.-1988.-62, N 10, pt 1.P. 703-707.

51. Retnakaran R., Shah B. R. Mild glucose intolerance in pregnancy and risk of cardiovascular disease: a population-based cohort study // Canad. Med. Assoc. J.-2009.-181, N 6-7.P. 371-376.

52. Peeters A., Barendregt J. J., Willekens F., Mackenbach J. P., Al Mamun A., Bonneux L., NEDCOM, the Netherlands Epidemiology and Demography Compression of Morbidity Research Group. Obesity in adulthood and its consequences for life expectancy: a life-table analysis // Ann. Intern. Med.2003.-138, N 1.-P. 24-32.

53. Calle E. E., Thun M. J., Petrelli J. M., Rodriguez C., Heath C. $W . J r$. Body-mass index and mortality in a prospective cohort of U.S. adults // N. Engl. J. Med.-1999.-- 341, N 15.P. 1097-1105.

54. Gunderson E. P., Quesenberry C. P. Jr., Lewis C. E., Tsai A. L., Sternfeld B., Smith W. D., Sidney S. Development of overweight associated with childbearing depends on smoking habit: The Coronary Artery Risk Development in Young Adults (CARDIA) Study // Obesity Res.-2004.-12, N 12.-P. 20412053.

55. Hobel C. J., Arora C. P., Korst L. M. Corticotrophin-releasing hormone and CRH-binding protein. Differences between 
patients at risk for preterm birth and hypertension // Ann. N. Y. Acad. Sci.-1999.-897.-P. 54-65.

56. Hobel C. J., Goldstein A., Barrett E. S. Psychosocial stress and pregnancy outcome // Clin. Obstet. Gynecol.-2008.-51, N 2.-P. 333-348.

57. Yan L. L., Liu K., Matthews K. A., Daviglus M. L., Ferguson T. F., Kiefe C. I. Psychosocial factors and risk of hypertension: the Coronary Artery Risk Development in Young Adults (CARDIA) study // JAMA.-2003.-290, N 16.P. $2138-2148$.

58. Krantz D. S., McCeney M. K. Effects of psychological and social factors on organic disease: a critical assessment of research on coronary heart disease // Annu. Rev. Psychol.2002.-53.-P. 341-369.

59. Brouwers E. P., van Baar A. L., Pop V. J. Does the Edinburgh postnatal depression scale measure anxiety? // J. Psychosom. Res.-2001.-51, N 5.-P. 659-663.
60. Campbell Ch. S., Moffatt R. J., Stamford B. A. Smoking and smoking cessation - the relationship between cardiovascular disease and lipoprotein metabolism: a review // Atherosclerosis.-2008.-201, N 2.-P. 225-235.

61. Ness R. B., Zhang J., Bass D., Klebanoff M. A. Interactions between smoking and weight in pregnancies complicated by preeclampsia and small-for-gestational-age birth // Am. J. Epidemiol.-2008.-168, N 4.-P. 427-433.

UDC $612.064 ; 364.25: 611.1$

Received 10.01 .10 